\title{
Improving the Outcome of Bone Marrow Transplantation by Using CD52 Monoclonal Antibodies to Prevent Graft-Versus-Host Disease and Graft Rejection
}

\author{
By Geoff Hale, Mei-J ie Zhang, Donald Bunjes, H. Grant Prentice, David Spence, Mary M. Horowitz, \\ A. J ohn Barrett, and Herman Waldmann
}

\begin{abstract}
Graft-versus-host disease (GVHD) is a major cause of mortality and morbidity after allogeneic bone marrow transplantation, but can be avoided by removing $T$ lymphocytes from the donor bone marrow. However, T-cell depletion increases the risk of graft rejection. This study examined the use of CD52 monoclonal antibodies to eliminate T cells from both donor marrow and recipient to prevent both GVHD and rejection. Seventy patients receiving HLA-identical sibling transplants for acute myelogenous leukemia (AML) in first remission were studied. An IgM (CAMPATH-1M) was used for in vitro depletion of the graft and an IgG (CAMPATH-1G) for in vivo depletion of the recipient before graft infusion. No posttransplant immunosuppression was given. Results were compared with two control groups: (1) 50 patients who received bone marrow depleted with CAMPATH-1M, but no CAMPATH-1G in vivo; and (2) 459 patients reported to the International Bone Marrow Transplant Registry (IBMTR) who received nondepleted grafts and conventional GVHD prophylaxis with cyclosporin A (CyA) and methotrexate (MTX). The incidence of acute GVHD was $4 \%$ in the treatment group compared with $35 \%$ in the CyA/MTX group $(P<.001)$.
\end{abstract}

$\mathbf{H}^{\prime}$ GH-DOSE CHEMOTHERAPY and radiotherapy followed by transplantation of allogeneic hematopoietic stem cells can cure patients with leukemia. However, allografts have several adverse effects, the most serious of which is graft-versus-host disease (GVHD). It can result in severe damage to skin, liver, and gut, frequently leading to death or chronic disability. To control GVHD, immunosuppressive drugs such as cyclosporin A (CyA), methotrexate (MTX), and corticosteroids are administered posttransplant. ${ }^{1,2}$ However, even with combined cyclosporin and methotrexate, GVHD remains the single most common cause of death after allogeneic transplants.
Chronic GVHD was also exceptionally low in the treatment group ( $3 \%$ v $36 \% ; P<.001$ ). The problem of graft rejection, which had been frequent in the historic CAMPATH-1M group (31\%), was largely overcome in the treatment group (6\%). Thus, transplant-related mortality of the treatment group (15\% at 5 years) was lower than for the CyA/MTX group (26\%; $P=.04)$. There was little difference in the risk of leukemia relapse between the treatment group (30\% at 5 years) and the CyA/MTX group (29\%). Survival of the treatment group at 6 months was better than the CyA/MTX group (92\% v 78\%), although at 5 years the difference was not significant ( $62 \% \mathrm{v} 58 \%$ ) and neither was the difference in leukemia-free survival (60\% v 52\%). We conclude that T-cell depletion is a useful strategy to prevent GVHD, provided that measures are taken to ensure engraftment. Using CAMPATH-1G to deplete residual host lymphocytes is a simple and practical method to do this. At least in AML, the beneficial reduction in GVHD can be achieved without an increased risk of relapse.

(C) 1998 by The American Society of Hematology.

For many years it has been known that GVHD can be prevented by depleting $\mathrm{T}$ lymphocytes from the donor bone marrow and a variety of methods were developed to accomplish this. ${ }^{3-8}$ One of the most widely used has been the monoclonal antibody (MoAb) CAMPATH-1M, a rat IgM antibody that recognizes the CD52 antigen. ${ }^{9}$ CD52 is abundantly expressed on all human lymphocytes and is an exceptionally good target for cell lysis by antibody with human complement; this provided a simple method for purging the donor T cells. ${ }^{10}$ Prior studies demonstrated the efficacy of T-cell depletion and consequent reduction in GVHD. ${ }^{6,11-14}$ However the benefit was
From the Sir William Dunn School of Pathology, University of Oxford, Oxford, UK; the Statistical Center, International Bone Marrow Transplant Registry, Milwaukee, WI; the Bone Marrow Transplant Unit, Ulm University Hospital, Ulm, Germany; the Department of Haematology, Royal Free Hospital and School of Medicine, London, UK; and the Department of Oncology, King Faisal Specialist Hospital, Riyadh, Saudi Arabia.

Submitted May 14, 1998; accepted August 13, 1998.

Antibody production for these studies was supported by the UK Medical Research Council, The Kay Kendall Leukaemia Fund, Wellcome Foundation Ltd, The EP Abraham's Trust. The IBMTR is funded by the following sources: Public Health Service Grant No. PO1 CA-40053 from the National Cancer Institute; the National Institute of Allergy and Infectious Diseases; the National Heart, Lung and Blood Institute; Contract No. CP-21161 from the National Cancer Institute of the US Department of Health and Human Services; Grant No. DAMD17-95-I-5002 from the Department of the US Army Medical Research and Development Command; and grants from Alpha Therapeutic Corp; Amgen, Inc; anonymous; Baxter Healthcare Corp; Bayer Corp; Blue Cross and Blue Shield Association; Lynde and Harry Bradley Foundation; Bristol-Myers Squibb Co; CellPro, Inc; Cell Therapeutics, Inc; Centeon; Center for Advanced Studies in Leukemia; Chimeric Therapies; Chiron Therapeutics, Inc; COBE BCT, Inc; Charles E. Culpeper Foundation; Eleanor Naylor Dana Charitable
Trust; Eppley Foundation for Research; Genentech, Inc; Glaxo Wellcome Co; ICN Pharmaceuticals; Immunex Corp; Kaiser Permanente; Kettering Family Foundation; Kirin Brewery Co; Robert J. Kleberg, Jr. and Helen C. Kleberg Foundation; Herbert H. Kohl Charities; Nada and Herbert P. Mahler Charities; MGI Pharma, Inc; Milstein Family Foundation; Milwaukee Foundation/Elsa Schoencich Research Fund; Samuel Roberts Noble Foundation; Novartis Pharmaceuticals; Ortho Biotech, Inc; John Oster Family Foundation; Jane and Lloyd Pettit Foundation; Alirio Pfffer Bone Marrow Transplant Support Association; Pfizer, Inc; Pharmacia and Upjohn; Principal Mutual Life Insurance Co; RGK Foundation; Rockwell Automation Allen Bradley Co; SangStat Medical Corp; Schering-Plough Oncology; Searle; Stackner Family Foundation; Starr Foundation; Joan and Jack Stein Charities; and Wyeth-Ayerst Laboratories.

Address reprint requests to Geoff Hale, PhD, Therapeutic Antibody Centre, Old Road, Headington, Oxford, OX3 7JT, UK; e-mail: geoff.hale@path.ox.ac.uk.

The publication costs of this article were defrayed in part by page charge payment. This article must therefore be hereby marked "advertisement" in accordance with 18 U.S.C. section 1734 solely to indicate this fact.

(c) 1998 by The American Society of Hematology.

0006-4971/98/9212-0024\$3.00/0 
offset by an increased risk of graft rejection by residual host $\mathrm{T}$ cells, ${ }^{15,16}$ and some patients suffered an increased risk of leukemia relapse due to the loss of graft-versus-leukemia effects contributed by donor lymphocytes. ${ }^{12,17}$ Animal models ${ }^{18,19}$ and clinical experience ${ }^{20,21}$ showed that graft rejection might be overcome by increasing the immunosuppression of the recipient before transplantation. One way of delivering this, without adding to the toxicity of the conditioning regimen, is to use MoAbs to deplete residual host $\mathrm{T}$ cells. ${ }^{22}$ A rat IgG2b CD52 antibody, CAMPATH-1G, effectively depletes human lymphocytes in vivo. ${ }^{23}$ Like CAMPATH-1M, it can activate human complement, although this is not sufficient for systemic T-cell depletion. Rat $\operatorname{IgG} 2 \mathrm{~b}$ also binds human $\mathrm{Fc}$ receptors and engages cellular killing mechanisms. ${ }^{24}$

A combined strategy using CAMPATH-1M to T-cell-deplete donor bone marrow and intravenous CAMPATH-1G to ablate residual host immunity has been used in more than 600 transplants worldwide, primarily in transplants from unrelated donors. ${ }^{13,14,25,26}$ We report here results of 70 HLA-identical sibling transplants for acute myelogenous leukemia (AML). We compare the results first to a historical group receiving CAMPATH-1M-treated marrow but no intravenous CAMPATH-1G and second to a matched group of concurrently treated patients reported to the International Bone Marrow Transplant Registry (IBMTR) who received unmanipulated transplants and posttransplant cyclosporin plus methotrexate for GVHD prophylaxis.

\section{MATERIALS AND METHODS}

MoAbs. CAMPATH- $1 \mathrm{G}^{27}$ was prepared from the culture supernatant of hybrid myeloma cell culture in a hollow-fiber fermentor (Acusyst-Jr; Cellex, Minneapolis, MN). It was purified by affinity chromatography on protein A sepharose, followed by ion exchange chromatography on S-sepharose, and formulated in phosphate-buffered saline. CAMPATH- $1 \mathrm{M}^{10}$ was prepared from hybrid myeloma cells using three methods: (1) ascitic fluid fractionated with ammonium sulphate, (2) hollow-fiber culture supernatant fractionated with ammonium sulphate, and (3) culture supernatant from stirred fermentors purified by affinity chromatography on protein A sepharose (this was performed by Wellcome Biotech [Beckenham, UK], who provided some of the antibody for this study). Batches prepared by each method were tested in a variety of analytical systems. All had comparable potency for complement-mediated cell lysis and insignificant effect on colony-forming cells. ${ }^{28,29}$ Process (1) was used for the historic controls, process (2) was used for the study patients at London and Riyadh, and process (3) was used for the study patients at Ulm.

In vitro T-cell depletion of bone marrow. A similar depletion procedure was used for all transplants, as described previously. ${ }^{11,25}$ Donor bone marrow was harvested in the usual way and processed using a cell separator to prepare a cell concentrate in balanced salt solution (containing $\mathrm{Ca}^{2+}$ ) that was free from plasma and depleted of red blood cells and granulocytes. The volume of the mononuclear cell suspension was adjusted so that the cell density did not exceed $5 \times 10^{7} / \mathrm{mL}$, and CAMPATH-1M was added to give a final concentration of $0.1 \mathrm{mg} / \mathrm{mL}$. The mixture was incubated for 10 to 20 minutes at room temperature, and then donor serum was added to a final concentration of $25 \%$ ( $\mathrm{vol} / \mathrm{vol})$. It was then incubated for a further 20 to 45 minutes at $37^{\circ} \mathrm{C}$. The treated bone marrow was washed once before infusion. Experiments had shown that differences in antibody batch or incubation timing did not materially affect the efficacy of T-cell depletion (G.H., unpublished work). The fraction of residual T cells was measured using standard methods, according to the practice in each center, either by E-rosettes or by fluorescence-activated cell sorting (FACS) analysis using appropriate T-cell-specific mouse MoAbs. (All of the study patients were assessed by FACS analysis using CD3 antibodies to enumerate T cells.)

In vivo administration of CAMPATH- $1 G$. Patients were treated with $20 \mathrm{mg} / \mathrm{d}$ of CAMPATH-1G over a period of 5 days at the beginning of the pretransplant conditioning therapy. Each dose was diluted in $250 \mathrm{~mL}$ normal saline and infused intravenously over 3 hours. To minimize the expected systemic first dose reaction, most patients received medication before the first antibody infusion, either 0.5 to $1 \mathrm{~g}$ prednisolone (Ulm) or $100 \mathrm{mg}$ hydrocortisone plus $50 \mathrm{mg}$ diphenhydramine (Royal Free, Riyadh), followed by $3 \times 1 \mathrm{~g}$ paracetamol daily.

Patients: Study group. Three transplant centers participated in the study: Ulm University Hospital (Ulm, Germany), Royal Free Hospital (London, UK), and King Faisal Hospital (Riyadh, Saudi Arabia). The original plan was to include all patients over 13 years with acute leukemia in first remission transplanted from HLA-matched siblings with the intent of comparing results in acute lymphoblastic leukemia (ALL) and AML. Because very few patients with ALL were recruited, this analysis focuses on patients with AML. (Inclusion of the ALL patients would not significantly affect the results.) The conditioning regimen was determined according to the standard protocol of each center. All included cyclophosphamide plus total body irradiation (TBI), which was administered as a single dose in $23 \%$ patients (at the Royal Free) and multiple fractions in the others (at Ulm and Riyadh). Additional chemotherapy (busulphan) was administered in 6\% of patients (Royal Free only). None of the patients received any additional lymphoid irradiation and none received posttransplant immunosuppression. There was no selection of patients according to cytogenetic risk group and data on risk groups were not reported systematically. Each center recruited consecutive patients provided that they gave informed consent. The numbers of patients and conditioning regimens at each center are shown in Table 1.

Patients: Historic CAMPATH-1M controls. A database is maintained by GH of all transplants using CAMPATH-1 antibodies. It contains information on the patient and donor characteristics and transplant outcomes. It is a condition of antibody supply that data are regularly reported to the CAMPATH users database. Controls were selected using the following criteria: (1) patients more than 13 years of age, (2) transplants for AML in first remission, (3) HLA-identical sibling donors, (4) conditioning regimens based on cyclophosphamide and TBI, (5) no lymphoid irradiation, (6) no intravenous CAMPATH-1G or other antibody, (7) T-cell depletion with CAMPATH-1M, and (8) no posttransplant immunosuppression. Fifty patients meeting these criteria were identified; 26 were transplanted at the same three centers as the 70 study patients.

Patients: IBMTR controls. A second control group of patients receiving non-T-cell-depleted transplants between 1984 and 1995 was selected from the IBMTR database using the same criteria described above, except that patients from the three study centers were excluded and GVHD prophylaxis was with combined CyA and MTX. ${ }^{30}$ IBMTR is a voluntary study group of over 300 transplant centers worldwide that contribute detailed data to a Statistical Center at the Medical College of Wisconsin. Participants are required to report all consecutive trans-

Table 1. Conditioning Regimens Used at the Three Study Centers

\begin{tabular}{lrrr}
\hline & Ulm & $\begin{array}{c}\text { Royal } \\
\text { Free }\end{array}$ & Riyadh \\
\hline No. of patients & 41 & 16 & 13 \\
TBI fractions (no.) & 6 & 1 & 6 \\
TBI total dose (rad) & 1,200 & 750 & 1,200 \\
TBI dose rate (rad/min) & 12 & 16 & 8 \\
$\begin{array}{l}\text { Time between last dose of antibody and } \\
\quad \text { transplant }\end{array}$ & $5 \mathrm{~d}$ & $1-3 \mathrm{~d}$ & $5 \mathrm{~d}$ \\
$\begin{array}{l}\text { Additional chemotherapy (no. of } \\
\quad \text { patients) }\end{array}$ & 0 & 4 & 0 \\
\hline
\end{tabular}


plants. The IBMTR database includes $40 \%$ to $45 \%$ of allogeneic transplant recipients since 1970 . Computerized error checks, physician review of submitted data, and on-site audits of participating centers ensure data quality. Selection of the control group proceeded as follows: patients with AML, transplanted in CR1 from 1984 through 1995 (inclusive), $\mathrm{N}=2,940$; exclude the three study centers, $\mathrm{N}=2,759$; select patients transplanted from HLA-identical siblings, $\mathrm{N}=2,429$; select cyclophosphamide + TBI with no ATG for conditioning, $\mathrm{N}=$ 1,307; select MTX plus CyA for GVHD prophylaxis, $\mathrm{N}=512$; and select patients more than 13 years of age at transplant, $\mathrm{N}=459$.

These 459 cases were reported to the IBMTR by 95 transplant centers.

Statistical analysis. Characteristics of the treatment groups were compared using the $\chi^{2}$ test for categorical variables and the Wilcoxon two-sample test for continuous variables. Comparing outcomes between the treatment groups required adjustment for the differences in baseline characteristics of the patients. First, associations between outcomes and potential prognostic variables were evaluated in each group separately using Cox proportional hazards regression with a forward stepwise approach. ${ }^{31}$ The outcomes considered were rate of engraftment (days to reach $0.5 \times 10^{9}$ neutrophils/L), graft failure, transplant-related mortality (TRM; defined as death in continuous complete remission), relapse, survival, and leukemia-free survival. Variables considered were age at transplant, recipient gender, donor gender, and year of transplant. Variables significantly associated with the outcome in any treatment group were included as covariates in subsequent comparisons. Possible interactions between significant covariates and the type of treatment were tested. The proportionality assumption of the Cox model was tested by adding a time-dependent covariate for each covariate. ${ }^{32}$ The proportionality assumption did not hold for treatment effects on survival, indicating that the relationship between treatment and survival outcomes differed over time. To determine regions of the treatment period where the relative risk of mortality between different treatments was a constant, a series of Cox models with different cut-off time points for time-dependent treatment effects were fitted. ${ }^{32}$ The final model chosen was the one giving the largest partial likelihood. In this model, treatment was considered as a time-dependent covariate with different coefficients from 0 to 6 and greater than 6 months since transplantation. The adjusted relative risks (95\% confidence intervals and $P$ values) of the study group versus historic group and study group versus MTX/CyA group were calculated for each outcome. Where appropriate, confidence intervals were calculated based on a log transformation.

\section{RESULTS}

T-cell depletion in vitro by CAMPATH-1M. Several methodologies were used over the years to estimate the fraction of residual T-cells in treated marrow (Table 2). The measured fraction of residual $\mathrm{T}$ cells in the study group (median, $0.4 \%$ ) was less than in the historic control group (median, $1.0 \% ; P=$ .024 ), but the result must be treated with caution owing to the potential variability in the measurement of small numbers of cells. The total number of mononuclear cells infused varied significantly between each of the three study centers and between the study group (median, $1.0 \times 10^{8} / \mathrm{kg}$ ) and the historic control group (median, $2.15 \times 10^{8} / \mathrm{kg} ; P<.001$ ). Consequently, the calculated numbers of $\mathrm{T}$ cells infused differed significantly between the study group (median, $0.2 \times 10^{6} / \mathrm{kg}$ ) and the historic group (median, $1.7 \times 10^{6} / \mathrm{kg} ; P<.001$ ).

Lymphocyte depletion in vivo by CAMPATH-1G. CAMPATH$1 \mathrm{G}$ treatment was started before other components of the conditioning regimen, so that antibody effects could be determined. All patients had rapid and profound depletion of blood lymphocytes. The number of clonable $\mathrm{T}$ cells that could be recovered from recipient blood samples obtained 1 to 2 days after the CAMPATH-1G infusions was reduced by 2.5 to 3 logs compared with pretreatment samples ${ }^{33}$ As in other studies with CAMPATH-1G or CAMPATH-1H, there was generally a firstdose effect of fever, often with rigors and nausea, which is related to a release of cytokines. ${ }^{34,35}$ In two patients the reaction was severe, and it was decided to discontinue CAMPATH-1G. (These patients are still included in the analysis.) All other patients had diminished reactions to the second and subsequent doses.

Effect of year of transplant. To determine whether patients transplanted before 1990 could be included in comparative analyses, we examined the IBMTR dataset for differences between patients transplanted in 1984 through 1989 compared with 1990 through 1995 . There were no statistically significant differences in the actuarial risks of transplant-related mortality (26\% v 27\% at 4 years), relapse (26\% v 33\% at 5 years), survival $(57 \% \vee 58 \%$ at 5 years), or leukemia-free survival (54\% v 49\% at 5 years). Therefore, all data from 1984 through 1995 were pooled for subsequent analyses.

Comparison of prognostic features of the study and control groups. Characteristics of the study and control groups are shown in Table 3. The most significant difference was in age. The median age of the study group (36 years) was significantly higher than the historic control (30 years; $P=.003$ ) or the CyA/MTX group (31 years; $P=.03$ ). There was also a difference in the gender of patients between the study group (57\% male) and the historic control (38\% male; $P=.04$ ), but not the CyA/MTX group (50\% male). The potentially confounding effect of patient age on the outcome has been adjusted in a multifactorial model (see below).

Comparison of outcome for study and control groups. Univariate analyses of outcome are shown in Table 4. Engraftment was significantly slower in both CAMPATH groups compared with the CyA/MTX group (Fig 1). Even disregarding patients who did not engraft at all, there was a delay of 1 day in

Table 2. Measured Extent of T-Cell Depletion In Vitro and Numbers of T Cells Infused

\begin{tabular}{lccccc}
\hline & UIm & Royal Free & Riyadh & Study Group & Historic Group \\
\hline No. of patients measured & 40 & 15 & 13 & 68 & 40 \\
Mononuclear cells $\left(\times 10^{8} / \mathrm{kg}\right)$ & $1.4(0.5-4.0)$ & $0.5(0.2-0.8)$ & $0.1(0.1-2.4)$ & $1.0(0.1-4.0)$ & $2.2(0.1-6.0)$ \\
T cells $(\%)$ & $0.8(0.0-3.0)$ & $0.2(0.0-7.5)$ & $0.2(0.0-2.7)$ & $0.4(0.0-7.5)$ & $1.0(0.0-10.0)$ \\
T cells infused $\left(\times 10^{6} / \mathrm{kg}\right)$ & $0.8(0.0-5.4)$ & $0.12(0.0-3.7)$ & $0.04(0.0-2.2)$ & $0.2(0.0-5.4)$ & $1.7(0.0-25.0)$ \\
\hline
\end{tabular}

Cell numbers are reported as medians, with the range in parentheses. There was a statistically significant difference between each study center in the total numbers of mononuclear cells $(P<.005)$, but there was no significant difference between centers in the percentage of residual T cells or the total numbers of T cells infused. However, there was a significant difference between the study group and the historic control group with regard to each of these parameters ( $P=.024$ for percentage of T cells and $P<.001$ for total T cells). 
Table 3. Features of Study and Control Groups

\begin{tabular}{lllllll}
\hline & & & & \multicolumn{2}{c}{ Significance } \\
\cline { 5 - 6 } & Study (1) & Historic (2) & CyA/MTX (3) & $P_{12}$ & $P_{13}$ \\
\hline $\begin{array}{l}\text { No. of patients } \\
\begin{array}{c}\text { Median year of } \\
\text { transplant }\end{array}\end{array}$ & 70 & 50 & 459 & & \\
$\begin{array}{c}\text { Median follow-up } \\
\text { (months) }\end{array}$ & 44 & 116 & 58 & $<.001$ & .01 \\
$\begin{array}{l}\text { Male patient } \\
\text { Male donor }\end{array}$ & $57 \%$ & $38 \%$ & $50 \%$ & .04 & .24 \\
$\begin{array}{l}\text { Median age at } \\
\text { transplant }\end{array}$ & $36(14-50)$ & $30(14-47)$ & $31(14-56)$ & .003 & .03 \\
\hline
\end{tabular}

The extreme range of the data is shown in parentheses. Probabilities $(P)$ are calculated by the $\chi^{2}$ test or Wilcoxon two-sample test as appropriate.

the median time to reach $0.5 \times 10^{9}$ neutrophils/L for the historic CAMPATH group and 5 days for the study group. There was a significant variation in time to engraftment among the three study centers. The median time to reach $0.5 \times 10^{9}$ neutrophils/L at Ulm was 23 days, whereas at the Royal Free and Riyadh, the median was 30 days $(P=.001)$. Platelet engraftment was not reported in this study.

The study group had a significantly lower risk of rejection than the historic group $(6 \% \vee 31 \% ; P=.0003)$ but a higher risk than the CyA/MTX group (2\%; $P=.03$; Fig 2$)$. The incidence of both acute and chronic GVHD was significantly lower in the study group compared with either of the two control groups. Only 3 of the 70 study patients developed grade 2 acute GVHD and 2 developed mild/moderate chronic GVHD; there were no more severe cases.

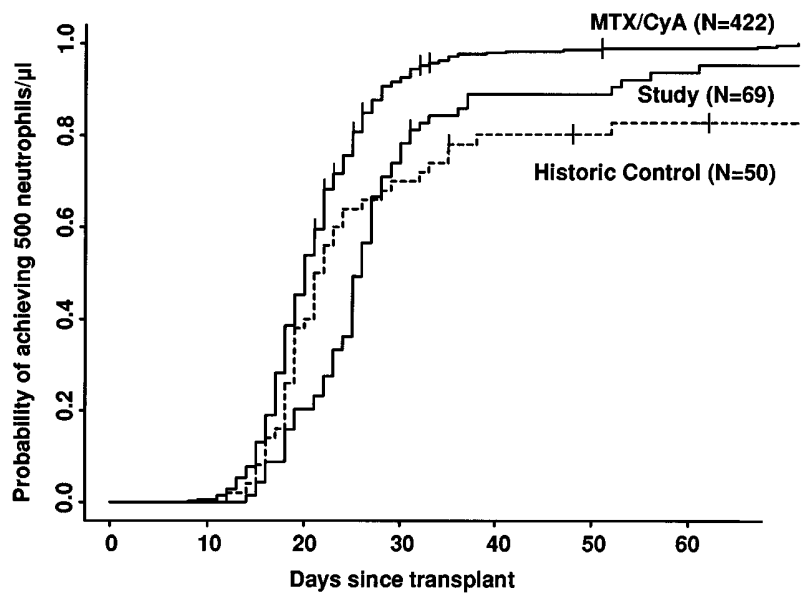

Fig 1. Speed of engraftment. Note the cross-over between study and control groups. The study group engrafts more slowly, but a higher proportion of patients eventually engraft.

Transplant-related mortality was significantly lower in the study group than in the historic group $(15 \% v 58 \% ; P<.0001)$ and also less than in the CyA/MTX group $(26 \% ; P=.04$; Fig 3 ). Relapse was similar in the three groups. Survival and leukemia-free survival were significantly higher in the study group than in the historic group, but similar to that in the CyA/MTX group (Figs 4, 5, and 6).

Outcome after graft failure/rejection. Primary failure of engraftment was documented in 9 of the historic control group (18\%) and 3 of the study group (4\%). Late graft rejection occurred in 6 of the historic group $(12 \%)$ and 1 of the study

Table 4. Outcome According to Treatment Group

\begin{tabular}{|c|c|c|c|c|c|}
\hline & \multicolumn{3}{|c|}{$\%$ Probability (95\% confidence interval) } & \multicolumn{2}{|c|}{ Significance } \\
\hline & Study (1) & Historic (2) & CYA/MTX (3) & $P_{12}$ & $P_{13}$ \\
\hline $0.5 \times 10^{9}$ neutrophils/L & & & & .84 & $<.0001$ \\
\hline By day 21 & $23(14,34)$ & $50(36,64)$ & $59(55,64)$ & & \\
\hline By day 30 & $78(67,87)$ & $70(57,82)$ & $93(90,95)$ & & \\
\hline By day 60 & $94(87,98)$ & $83(71,92)$ & $99(97,100)$ & & \\
\hline Graft failure & & & & .0003 & .03 \\
\hline At $1 \mathrm{mo}$ & $4(1,11)$ & $20(10,32)$ & $1(0,3)$ & & \\
\hline At $12 \mathrm{mo}$ & $6(2,13)$ & $31(19,45)$ & $2(1,3)$ & & \\
\hline \multicolumn{6}{|l|}{ Acute GVHD } \\
\hline Grade II-IV & 4 & 20 & 35 & .01 & $<.001$ \\
\hline \multicolumn{6}{|l|}{ Chronic GVHD } \\
\hline Grade I-IV (limited-extensive) & 3 & 21 & 36 & .005 & $<.001$ \\
\hline Transplant-related mortality & & & & $<.0001$ & .06 \\
\hline At 3 yrs & $15(7,25)$ & $53(38,67)$ & $25(21,29)$ & & \\
\hline At 5 yrs & $15(7,25)$ & $58(43,72)$ & $26(22,31)$ & & \\
\hline Relapse & & & & .54 & .67 \\
\hline At $3 y r s$ & $27(17,39)$ & $22(9,38)$ & $24(20,29)$ & & \\
\hline At 5 yrs & $30(19,42)$ & $22(9,38)$ & $29(24,35)$ & & \\
\hline Survival & & & & .001 & .27 \\
\hline At $3 \mathrm{yrs}$ & $65(53,76)$ & $39(26,53)$ & $59(55,64)$ & & \\
\hline At 5 yrs & $62(50,74)$ & $35(22,49)$ & $58(53,62)$ & & \\
\hline Leukemia-free survival & & & & .002 & .24 \\
\hline At 3 yrs & $62(50,73)$ & $37(24,51)$ & $57(52,62)$ & & \\
\hline At 5 yrs & $60(47,71)$ & $33(21,47)$ & $52(47,57)$ & & \\
\hline
\end{tabular}

The outcome is reported, together with the $95 \%$ confidence interval. Significance $(P)$ values in this table (except for GVHD) were calculated from a univariate long-rank test (ie, they do not take into account any potential covariates). 


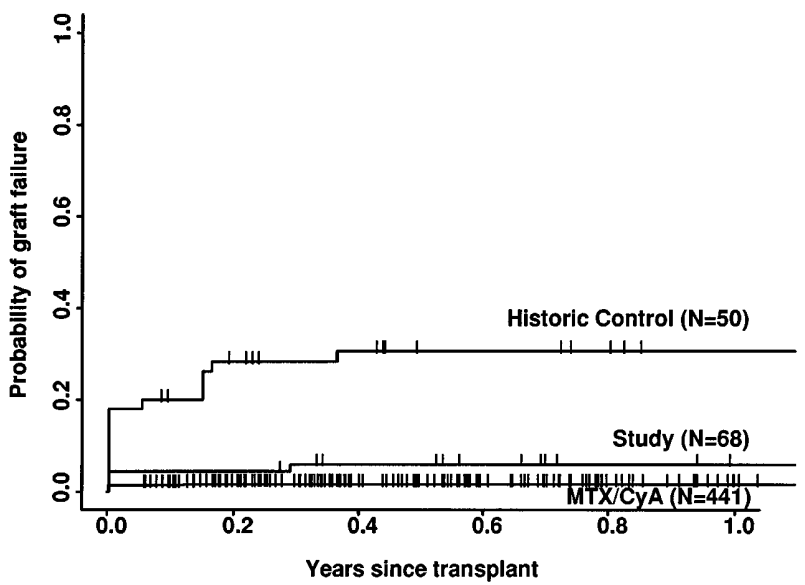

Fig 2. Risk of graft failure.

group (1\%). It was not possible to determine the cause of graft failure in every case, but it is likely that most, if not all, were due to immunological rejection. Therefore, both early and late graft failure were analyzed together. Patients were treated by reinfusion of stored autologous marrow (5 historic control and 1 study) or by a second transplant of unfractionated allogeneic marrow from the original donor (6 historic control and 3 study). In 11 cases, these rescue procedures resulted in successful engraftment, but many of the patients suffered further complications and eventually 12 of 15 patients died in the historic group ( 9 from graft failure) and 4 of 4 patients died in the study group (all from relapse).

Multivariate analysis. The results were further analyzed using the Cox proportional regression model to test for interactions with prognostic factors that might have affected the results of univariate analyses (Table 5). Variables used in building the model were age, year of transplant, patient gender, donor gender, and treatment group. Outcomes were rate of engraftment, graft failure, transplant-related mortality, relapse, survival, and leukemia-free survival. There was a significant association between age and transplant-related mortality. The relative risk of transplant-related mortality for patients more

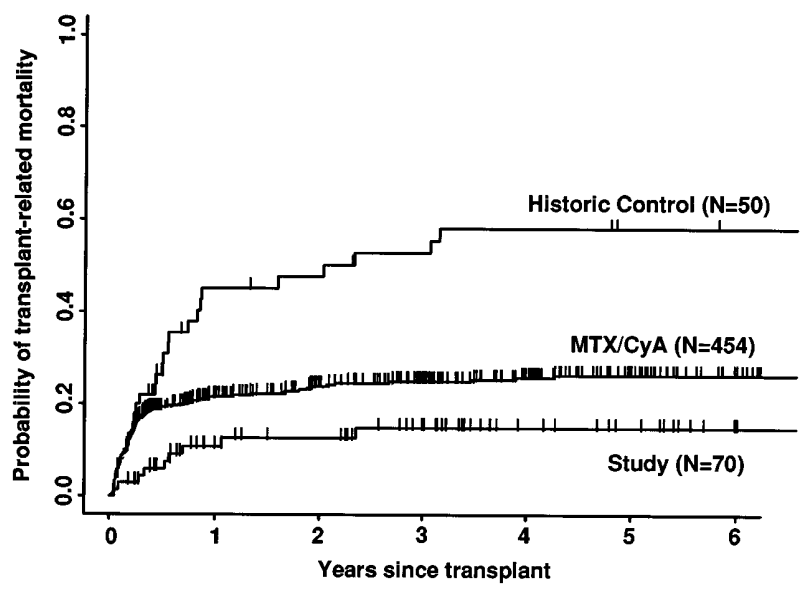

Fig 3. Probability of transplant-related mortality (death in continuous complete remission). Note the significantly reduced mortality of the study group in the first 6 months.

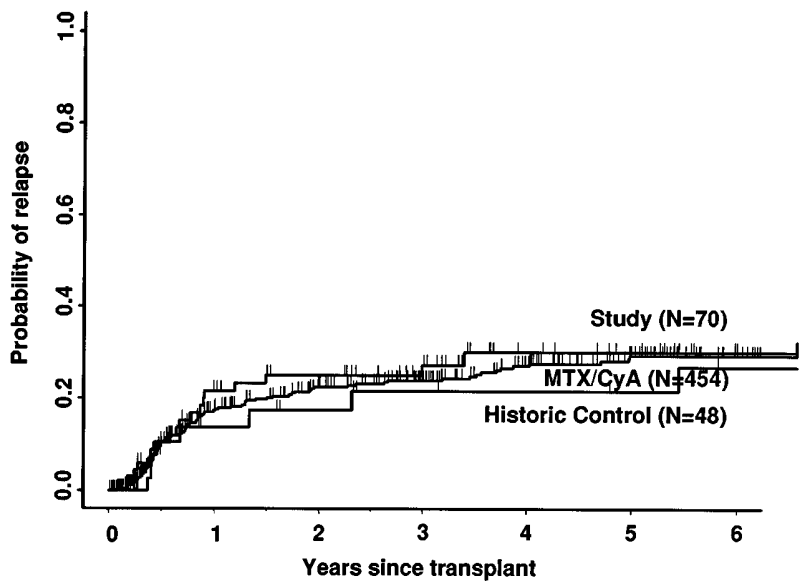

Fig 4. Probability of relapse.

than 30 years of age was 1.53 times that for patients under 30 years (95\% confidence interval, 1.08 to $2.15 ; P=.02$ ). However, the relationship between patient groups and outcome was similar for young and old patients. In the final model, allowing for the effect of age, there was less than half the risk of transplant-related mortality in the study group compared with the CyA/MTX control (relative risk, .45; $P=.02$ ). Tests for proportionality indicated that the effect of the study treatment on survival differed at different times after the transplant. In the first 6 months after the transplant, survival of patients in the study group was significantly higher than the control groups; among patients surviving 6 months, subsequent survival was similar in the study group versus the two control groups. It is not surprising that no significant difference in long-term survival could be shown, because the size of the study did not give it sufficient power to demonstrate even a $10 \%$ difference.

Causes of death. The underlying causes of death in each patient group are reported in Table 6. Because of the small numbers in the study and historic control group and the difficulties inherent in assigning a single cause of death to some patients, we did not attempt formal statistical analysis. The most frequent cause of death in the study group was relapse (15 patients), followed by infection (7 patients). There were 3

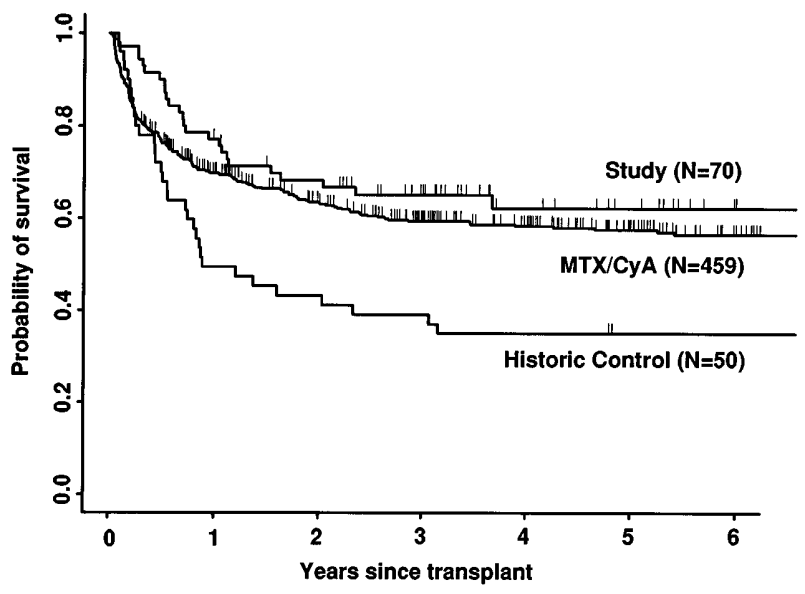

Fig 5. Probability of survival. 


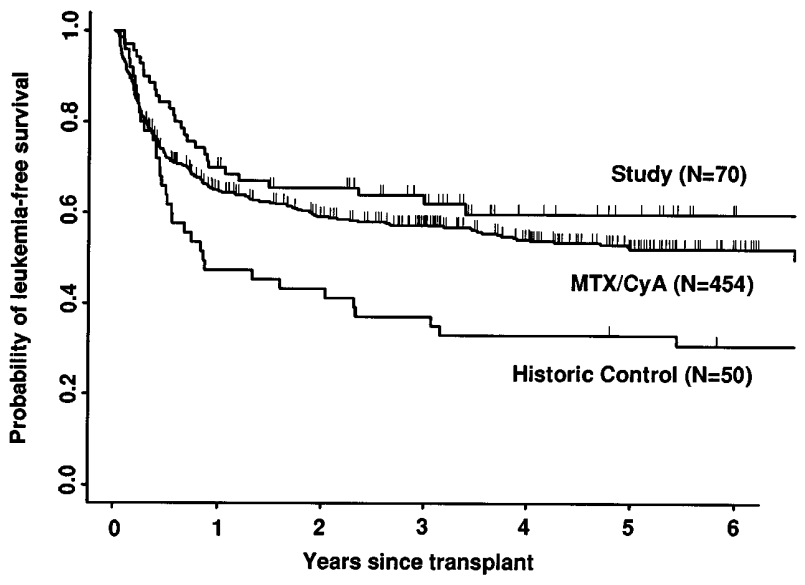

Fig 6. Probability of leukemia-free survival.

deaths from infection in the study group after 6 months: 1 varicella zoster + aspergillus (day 191), 1 varicella zoster + hepatitis C (day 858), and 1 unknown organism (day 387).

\section{DISCUSSION}

Since the early clinical trials of T-cell depletion, it was realized that graft rejection by residual host $\mathrm{T}$ cells was a major problem that negated much of the clinical benefit of avoiding GVHD. Graft rejection could be reduced, but not eliminated, by giving extra whole body ${ }^{20}$ or total lymphoid irradiation ${ }^{21}$ or by administering posttransplant CyA. ${ }^{13}$ Animal experiments showed that anti-T-cell MoAbs could be used to escalate the immunosuppression without toxicity, and this prompted the collaborative CAMPATH users group to begin a number of pilot studies using CAMPATH-1G to deplete residual host T cells. ${ }^{13,14,25,26}$ These studies gave encouraging results, but it was possible that other improvements in transplant protocols over time might have influenced the outcome. Therefore, we performed the present comparison with a large contemporaneous control group of patients selected from the IBMTR database. A second

Table 5. Analysis of Outcome According to a Multivariate Model

\begin{tabular}{cccccc}
\hline & \multicolumn{2}{c}{$\begin{array}{c}\text { Study } v \\
\text { Historic Control }\end{array}$} & & \multicolumn{2}{c}{$\begin{array}{c}\text { Study } v \\
\text { CyA/MTX Control }\end{array}$} \\
\cline { 2 - 3 } Outcome & $\mathrm{RR}(95 \% \mathrm{Cl})$ & $P$ & & $\mathrm{RR}(95 \% \mathrm{Cl})$ & $P$ \\
\hline $\begin{array}{c}\text { Graft failure } \\
\text { Transplant-related } \\
\quad \text { mortality }\end{array}$ & $.17(.06, .51)$ & .002 & & $3.53(1.03,12.05)$ & .04 \\
$\begin{array}{c}\text { Relapse } \\
\text { Death }\end{array}$ & $.20(.09, .43)$ & $<.0001$ & $.45(.23, .90)$ & .02 \\
$\quad<6$ mo & $1.33(.58,3.07)$ & .50 & & $1.11(.67,1.84)$ & .68 \\
$>6$ mo & $.30(.12, .75)$ & .01 & $.38(.18, .82)$ & .01 \\
$\begin{array}{c}\text { Death and/or } \\
\text { relapse }\end{array}$ & $.55(.28,1.07)$ & .08 & & $1.37(.82,2.30)$ & .23 \\
\hline
\end{tabular}

The Cox proportional regression model was used to allow for factors that might influence the outcome other than the treatment group. The only relevant factor was patient age. The adjusted relative risks (RR) for transplant outcome according to treatment group are shown, together with the $95 \%$ confidence interval $(\mathrm{Cl})$ and the significance $(P)$. A relative risk less than 1.0 means the outcome was less likely in the study group compared with the control group; a figure more than 1.0 means that the outcome was more likely.
Table 6. Causes of Death According to Treatment Group

\begin{tabular}{lccc}
\hline & Study & Historic & CyA/MTX \\
\hline Graft failure/rejection & 1 & 9 & 1 \\
GVHD & 0 & 2 & 36 \\
Relapse & 15 & 6 & 56 \\
Infection & 7 & 8 & 26 \\
Other (eg, cardiovascular, conditioning & & & \\
$\quad$ toxicity) & 2 & 4 & 58 \\
Secondary malignancy & 0 & 1 & 1 \\
Unknown & 0 & 2 & 5 \\
Total & 25 & 32 & 183 \\
\hline
\end{tabular}

A single underlying cause of death was assigned to each patient. Because of the small numbers, the differences in follow-up times (see Table 3), and the difficulty in assigning a unique cause to each case, statistical analysis is deemed to be impracticable.

problem associated with T-cell depletion is the loss of beneficial graft-versus-leukemia effects. This is well documented for patients with chronic myeloid leukemia (CML), but it is not clear whether there is a significant effect in patients with acute leukemia. In this analysis, we evaluated relapse in patients transplanted for AML in first complete remission.

This study convincingly demonstrates the effectiveness of the combined CD52 antibodies in dramatically reducing the risk of acute and chronic GVHD, without posttransplant immunosuppression. There were no cases of severe acute or chronic GVHD in the study group. Similar results have been reported when the same antibody protocol was used in other transplant indications. ${ }^{14,26}$ The addition of CAMPATH-1G in vivo pretransplant resulted in lower GVHD rates than those seen in the historic controls, which might be due to additional depletion of donor $\mathrm{T}$ cells in vivo by residual CAMPATH-1G at the time of transplant. The measured extent of T-cell depletion by CAMPATH-1M was greater for the study patients than the historic controls, but the significance of this is hard to assess due to the technical difficulties in accurate measurement of small numbers of $\mathrm{T}$ cells and the fact that actual depletion is likely to have been greater than measured, because residual $\mathrm{T}$ cells would be coated with CAMPATH-1M antibody and lysed when they encounter fresh complement after infusion of the bone marrow.

Importantly, the study group also had a significantly lower risk of graft failure than the historic control (6\% at 12 months). This is still higher than in the non-T-cell-depleted group (2\%), but acceptable, given the much lower risk of GVHD. Possibly graft failure would be reduced still further if larger numbers of stem cells were infused, as is now possible using peripheral blood harvests. Despite the improvement in overall engraftment, the speed of engraftment, as measured by the time to reach $0.5 \times 10^{9}$ neutrophils/L, was significantly slower in the study group compared with either control group (after excluding graft failure). The most likely explanation for this delay is the comparatively small number of mononuclear cells infused in the study group, especially because the greatest delay was observed at the two centers where the smaller numbers of cells were infused (Table 2). Experimental models have shown that speed of engraftment is related to total stem cell dose, ${ }^{36}$ and this has been confirmed in a recent multifactorial analysis of the whole CAMPATH users database (G.H. and S.P. Cobbold, 
unpublished work). Rapid engraftment has been reported with CAMPATH-1-treated stem cells from peripheral blood. ${ }^{37}$

The relative risk of transplant-related mortality was significantly lower in the study group compared with the CyA/MTX group $(15 \% v 26 \%)$. This is most likely due to reducing the incidence and severity of GVHD, although we cannot rule out a benefit due to the avoidance of toxicity of the immunosuppressive drugs themselves or consequent infection risks. One of the most important parameters in the long-term follow-up was the risk of relapse, because it has been shown that T-cell depletion increases relapse risk substantially for $\mathrm{CML},{ }^{17,38}$ and it is suggested that there could be a modest increase in risk for acute leukemias. In contrast, we found no significant difference between the study group (30\% risk of relapse at 5 years) and the CyA/MTX group (29\%), supporting the concept that the impact of T-cell-mediated graft-versus-leukemia reactions is minimal in patients transplanted for acute leukemia in first remission. ${ }^{13}$ Overall survival was significantly better in the study group compared with the CyA/MTX group up to 6 months; subsequent survival and leukemia-free survival were slightly, but not significantly better.

Prospective randomized studies are often thought to be the gold standard in evaluating new treatments, but their application in transplantation is hindered by the relative infrequency of the diseases treated and the fact that only a minority of patients have suitable donors. This makes accrual of sufficient patients difficult, if not impossible. We were primarily interested in measuring differences in the risk of graft failure, where the expected results were in the range of $2 \%$ to $15 \%$. Hundreds of patients would be required to give an adequate power. Fortunately, a better alternative is available. Large clinical databases, such as the one maintained by the IBMTR, contain data on a large proportion of transplant recipients worldwide with details of prognostic and treatment factors that allow application of sophisticated statistical techniques to adjust for differences between groups and exploit the power of large numbers. ${ }^{39}$ In the current study, we identified 459 suitable controls receiving the most common approach to GVHD prophylaxis against which the combined antibody strategy could be compared. Unlike many prospective randomized trials, in which significant differences are sometimes attributed to unusually poor performance of the control group, we can be sure that our CyA/MTX control group is truly representative. The accuracy of the control data are confirmed by published results from the European Transplant Registry on an overlapping set of patients, where the outcomes are superimposable. ${ }^{40}$ However, it might be argued that the three study centers shared some favorable factor in common other than the treatment protocol. In fact, the three centers were more remarkable for their diversity in approaches to transplantation. Furthermore, this idea is negated by the published comparison from one center (Ulm) of study patients compared with their own CyA/MTX control group. ${ }^{25}$ The results are very similar to those presented here, except of course for the smaller numbers of control patients. The limitations of our analysis should be recognized, particularly the difficulty of allowing for possible differences in relapse risk according to AML subtype, prior therapy, and conditioning regimen, but we can be confident that the control group is representative of contemporary clinical practice.
Immune reconstitution was not specifically studied here, but results for marrow transplants depleted with CAMPATH-1M have been reported previously. ${ }^{41-43}$ All of these reports agree that lymphocyte recovery, particularly of $\mathrm{CD}^{+}$cells, is slow compared with T-replete transplants. There does not appear to be a substantial long-term mortality as a result of opportunistic infections, but this requires continued surveillance. Some groups report an early increase in the frequency of cytomegalovirus (CMV) reactivation, although this did not necessarily lead to severe clinical disease. ${ }^{44}$ The cellular distribution of the CD52 antigen may be fortuitous in this regard. NK cells are relatively spared by CAMPATH-1, ${ }^{11,45}$ and it has been suggested that they may play a role in control of CMV disease and have an antileukemia effect. ${ }^{46-51}$ However, B cells are efficiently depleted. Elsewhere, we have reported that T-cell depletion with CAMPATH-1 antibodies does not give rise to an excess of B-cell lymphoproliferative disorders, in contrast to some other methods of T-cell depletion. ${ }^{52}$ We believe this is because depletion of donor B cells removes both a potential reservoir of virus and its major target.

In this trial, CAMPATH-1G was used as a form of monoclonal antilymphocyte globulin to achieve the additional depletion of recipient lymphocytes required to permit engraftment of T-cell-depleted bone marrow. The positive outcome is in accord with animal experiments, confirming that graft failure was caused by lymphocyte-mediated rejection. The logical development is to use the IgG antibody CAMPATH-1G (or its humanized equivalent CAMPATH-1H) for depletion of both donor and recipient $\mathrm{T}$ cells, and current trials are aimed at developing the simplest and most effective way to administer it - either in vivo before and after the transplant ${ }^{14,53,54}$ or as a single dose, mixed and infused with the donor bone marrow. ${ }^{13,55}$ This study confirms that T-cell depletion is the best way to prevent GVHD. Our approach largely avoids graft rejection and does not result in an increased risk of relapse, at least in AML patients. The disease-free survival achieved is at least as good as with conventional regimens, but with the following important advantages: (1) posttransplant immunosuppression is no longer needed and (2) almost complete elimination of acute and chronic GVHD should translate into a substantially better quality of life for the survivors.

\section{ACKNOWLEDGMENT}

The authors are indebted to many colleagues who played an important part in the production of antibodies, care of patients, data collection, and analysis, including Jenny Phillips and the staff of the Therapeutic Antibody Centre (Cambridge, UK), Marcus Wiesneth, Bernd Hertenstein, Renate Arnold (Ulm, Germany), Mike Hamon, Ian MacDonald, Grazyna Galatowicz, Chris Collins (Royal Free, London, UK), Hugh Clink, Andrew Padmos, Peter Ernst, and Kirtikant Sheth (Riyadh, Saudi Arabia) as well as the following transplant teams throughout the world who contributed to the registry data. Australia: Royal Prince Alfred Hospital, Camperdown; Alfred Hospital, Prahran; Westmead Hospital, Westmead; Austria: Univ. Klinik fur Innere Medizin I, Vienna; Belgium: A.Z. Sint-Jan, Brugge; Cliniques Universitaires Saint-Luc, Brussels; University Hospital Gasthuisberg, Leuven; University of Liege, Liege; Brazil: Hospital de Clinicas, Curitiba; Centro Nacional de Transplate de Medula Ossea-CEMO, Rio de Janeiro; Canada: Ontario Cancer Instute, Princess Margaret Hospital, Toronto; China: Bei Tai Ping Lu Hospital, Beijing; Croatia: Centar za 
Transplataciju Kostane Srzi, Zagreb; Cuba: Institute de Hematologia e Immunologia, Ciudad de la Havana; Czech Republic: Institute of Hematology and Blood Transfusion, Praha 2; Finland: Helsinki University Central Hospital, Helsinki 29; Turku University Central Hospital, Turka 52; France: CHRU, Angers; Chu Clemenceau, Caen; Hopital A. Michallon, Grenoble; Centre Hospitalier Regional de Lille, Lille; Institut J. Paoli I. Calmettes, Marseille; Hopital Saint Louis, Paris; Hopital Saint-Antoine, Paris; Hotel Dieu de Paris, Paris; Groupe Hospitalier du haut Leveque, Pessac; Hopital Jean Bernard, Poiters; Center Henri Becquerel (C.R.L.C.C.), Rouen; Hopital de Purpan, Toulouse; Hopital D’Enfants, Vandoeuvre Les Nancy; Germany: Universitatsklinikum Rudolf Virchow, Berlin; Zentrum fur Knochenmark Transplantation, Hamburg; Medizinische Hochschule Hannover, Hannover; Christian-Albrechts-University, Kiel, Kiel; Universitat Munchen, Munchen; Ulm University Hospital, Ulm; Hungary: National Institute of Hematology, Budapest; Ireland: St. James's Hospital, Dublin; Italy: Spedali Civili-Brescia, Brescia; Ospedale San Martino, Genoa; Centro Trapianti Midollo Osseo via fonte Romana, Pescara; Ospedale San Camillo, Roma; Ospedale Molinette, Torino; Japan: Chiba University School of Medicine, Chuo-Ku; Osaka Medical Centre for Cancer \& Cardiovascular Diseases, Osaka: Korea: Catholic University Medical College, Yongdungpo-Gu; New Zealand: University of Auckland Hospital, Auckland; Canterbury Health Laboratory, Christchurch-NZ; Russia: Clinical Hospital Number 6, Moscow; Saudi Arabia: King Faisal Hospital, Riyadh; Spain: Hospital General Vall d'Hebron, Barcelona; Hospital Sant Pau, Barcelona; Postgraduate School of Haematology, Barcelona; Hospital de la Princesa, Madrid; Hospital Puerta de Hierro, Madrid; Hospital Marques de Valdecilla, Santander; Hospital La Fe, Valencia; Sweden: Huddinge Hospital, Huddinge; University Hospital of Lund, Lund; Switzerland: Kantonsspital, Basel; Kantonsspital Zurich, Zurich; Taiwan: Veteran's General Hospital-Taipei, Taipei; The Netherlands: Leiden University Hospital, Leiden; Turkey: Ankara University Medical School, Ankara; United Kingdom: Birmingham Heartlands Hospital, Birmingham; The Queen Elizabeth Hospital, Birmingham; The Royal Infirmary of Edinburgh, Edinburgh; Glasgow Royal Infirmary, Glasgow; St. James University Hospital, Leeds; Royal Infirmary, Leicester; Imperial College School of Medicine, London; Royal Free Hospital, London; Royal Marsden Hospital, London; The London Clinic, London; Westminster Hospital, London; The Royal Victoria Infirmary, Newcastle Upon Tyne; Nottingham City Hospital, Nottingham; United States: Egleston Hospital for Children at Emory University, Atlanta, GA; Roswell Park Cancer Institute, Buffalo, NY; Medical University of South Carolina, Charleston, SC; University of Virginia Charlottesville, Charlottesville, VA; Children's Hospital Medical Center, Cincinnati, OH; De University Medical Centre, Durham, NC; University of Florida, Gainesville, FL; St. Francis Medical Centre, Honolulu, HI; MD Anderson Cancer Center, Houston, TX; Indiana University Medical Center \& Outpatient Center, Indianapolis, IN; University of Kansas Medical Center, Kansas City, KS; UCLA Center for Health Sciences, Los Angeles, CA; University of Louisville, Louisville, KY; University of Wisconsin Hospital \& Clinics, Madison, WI; University of Minnesota Hospital \& Clinics, Minneapolis, MN; Louisiana State University Medical Center, New Orleans, LA; University of Oklahoma Health Sciences Center, Oklahoma City, OK; University of Nebraska Medical Center, Omaha, NE; St. Joseph's Hospital \& Medical Center, Paterson, NJ; Intermountain Health Care, Inc, LDS Hospital, Salt Lake City, UT; Wilford Hall Medical Center, San Antonio, TX; Mayo Clinic Scottsdale, Scottsdale, AZ; George Washington University Medical Center, Washington, DC; Georgetown University Medical Center, Washington, DC.

\section{REFERENCES}

1. Gluckman E: Immunosuppressive drugs for the prevention of acute graft-vs-host disease, in Burakoff SJ, Deeg HJ, Ferrara J, Atkinson
K (eds): Graft-vs-Host Disease Immunology, Pathophysiology and Treatment. New York, NY, Marcel Dekker, 1990, p 389

2. Atkinson K: Treatment of extensive human chronic graft-vs-host disease, in Burakoff SJ, Deeg HJ, Ferrara J, Atkinson K (eds): Graft-vs-Host Disease Immunology, Pathophysiology and Treatment. New York, NY, Marcel Dekker, 1990, p 681

3. Reisner Y, Kapoor N, Kirkpatrick D, Pollack MS, Dupont B, Good RA, O'Reilly RJ: Transplantation for acute leukaemia with HLA-A and B nonidentical parental marrow cells fractionated with soybean agglutinin and sheep red blood cells. Lancet 2:327, 1981

4. Prentice HG, Blacklock HA, Janossy G, Bradstock KF, Skeggs D, Goldstein G. Hoffbrand AV: Use of anti-T cell monoclonal antibody OKT3 to prevent acute graft versus host disease in allogeneic bone marrow transplantation for acute leukemia. Lancet 1:700, 1982

5. Prentice HG, Janossy G, Price-Jones L, Trejdosiewicz LK, Panjwani D, Graphakos S, Ivory K, Blacklock HA, Gilmore MJML, Tidman N, Skeggs DBL, Bail S, Patterson J, Hoffbrand AV: Depletion of $\mathrm{T}$ lymphocytes in donor marrow prevents significant graft-versushost disease in matched allogeneic leukaemic marrow transplant recipients. Lancet 1:472, 1984

6. Waldmann H, Or R, Hale G, Weiss L, Cividalli G, Samuel S, Manor D, Brautbar C, Polliack A, Rachmilewitz EA, Slavin S: Elimination of graft versus host disease by in vitro depletion of alloreactive lymphocytes using a monoclonal rat anti-human lymphocyte antibody (CAMPATH-1). Lancet 2:483, 1984

7. Noga SJ, Donnenberg AP, Schwartz CL, Strauss LC, Civin CI, Santos GW: Development of a simplified centrifugation elutriation procedure for depletion of lymphocytes from human bone marrow. Transplantation 41:214, 1986

8. Filipovitch AH, Vallera DA, Youle RJ, Haake R, Blazar BR, Arthur D, Neville Ramsay NK, McGlave P, Kersey JH: Graft-versushost disease prevention in allogeneic bone marrow transplantation from histocompatible siblings. A pilot study using immunotoxins for $\mathrm{T}$ cell depletion of donor bone marrow. Transplantation 44:62, 1987

9. Hale G: Campath-1 Antigen (CD52), in Delves PJ, Roitt I (eds) Encyclopedia of Immunology London, UK, Academic, 1998, p 402

10. Hale G, Bright S, Chumbley G, Hoang T, Metcalf D, Munro AJ, Waldmann $\mathrm{H}$ : Removal of $\mathrm{T}$ cells from bone marrow for transplantation: A monoclonal antilymphocyte antibody that fixes human complement. Blood 62:873, 1983

11. Heit W, Bunjes D, Weisneth M, Schmeiser T, Arnold R, Hale G, Waldmann $\mathrm{H}$, Heimpel $\mathrm{H}$ : Ex vivo T-cell depletion with the monoclonal antibody Campath-1 plus human complement effectively prevents acute GvHD in allogeneic bone marrow transplantation. $\mathrm{Br} \mathrm{J}$ Haematol 64:479, 1986

12. Hale $\mathrm{G}$, Cobbold $\mathrm{S}$, Waldmann $\mathrm{H}$ : $\mathrm{T}$ cell depletion with CAMPATH-1 in allogeneic bone marrow transplantation. Transplantation 45:753, 1988

13. Hale G, Waldmann H, for CAMPATH users: Control of graftversus-host disease and graft rejection by $\mathrm{T}$ cell depletion of donor and recipient with CAMPATH-1 antibodies. Results of matched sibling transplants for malignant diseases. Bone Marrow Transplantation 13:597, 1994

14. Hale G, Waldmann H, for CAMPATH users: CAMPATH-1 monoclonal antibodies in bone marrow transplantation. Hematotherapy $3: 15,1994$

15. Bunjes D, Heit W, Arnold R, Schmeiser T, Wiesneth M, Carbonell F, Porzsolt F, Raghavachar A, Heimpel H: Evidence for the involvement of host-derived OKT8-positive T cells in the rejection of T-depleted HLA-identical bone marrow grafts. Transplantation 43:501, 1987

16. Kernan NA, Flomenberg N, Dupont B, O'Reilly RJ: Graft rejection in recipients of T-cell depleted HLA-identical marrow transplants for leukemia. Identification of host-derived anti-donor allocytotoxic T lymphocytes. Transplantation 43:842, 1987 
17. Apperley JF, Mauro FR, Goldman JM, Gregory W, Arthur CK, Hows J, Arcese W, Papa G, Mandelli F, Wardle D, Gravett P, Franklin I, Bandini G, Ricci P, Tura S, Iacone A, Torlontano G, Heit W, Champlin $\mathrm{R}$, Gale RP: Bone marrow transplantation for chronic myeloid leukaemia in first chronic phase: Importance of a graft-versus-leukaemia effect. Br J Haematol 9:239, 1988

18. Wagemaker G, Vriesendorp HM, van Bekkum DW: Successful bone marrow transplantation across major histocompatibility barriers in rhesus monkeys. Transplant Proc 13:875, 1981

19. Vriesendorp HM, Klapwijk WM, Heidt DJ, Hogeweg B, Zurcher C, van Bekkum DW: Factors controlling the engraftment of transplanted dog bone marrow cells. Tissue Antigens 20:63, 1982

20. Patterson J, Prentice HG, Brenner MK, Gilmore M, Janossy G, Ivory-K, Skeggs D, Morgan H, Lord J, Blacklock HA, Hoffbrand AV, Apperley JF, Goldman JM, Burnett A, Gribben J, Alcorn M, Pearson C, McVickers I, Hann IM, Reid C, Wardle D, Gravett PJ, Bacigalupo A, Robertson AG: Graft rejection following HLA matched T-lymphocyte depleted bone marrow transplantation. Br J Haematol 63:221, 1986

21. Slavin S, Or R, Naparstek E, Cividalli G, Weshler Z, Weiss L, Mumcuoglu M, Engelhard D, Aker M, Pollack A, Ben-Yehuda A, Brautbar C, Hale G, Waldmann H: New approaches for the prevention of rejection and graft-vs.-host disease in clinical bone marrow transplantation. Isr J Med Sci 22:264, 1986

22. Cobbold SP, Martin G. Waldmann H: Monoclonal antibodies for the prevention of graft-versus-host disease and marrow graft rejection: The depletion of T-cell subsets in vitro and in vivo. Transplantation 42:239, 1986

23. Dyer MJS, Hale G, Hayhoe FGJ, Waldmann H: Effects of CAMPATH-1 antibodies in vivo in patients with lymphoid malignancies: Influence of antibody isotype. Blood 73:1431, 1989

24. Hale G, Clark M, Waldmann H: Therapeutic potential of rat monoclonal antibodies: Isotype specificity of antibody-dependant cellmediated cytotoxicity with human lymphocytes. J Immunol 134:3056, 1985

25. Bunjes D, Hertenstein B, Wiesneth M, Stefanic M, Novotny J, Danoker C, Heit W, Arnold R, Heimpel H: In vivo/ex vivo $\mathrm{T}$ cell depletion reduces the morbidity of allogeneic bone marrow transplantation in patients with acute leukaemia in first remission without increasing the risk of treatment failure: Comparison with cyclosporin/ methotrexate. Bone Marrow Transplant 15:563, 1995

26. Oakhill A, Pamphilon DH, Potter MN, Steward CG, Goodman S, Green A, Goulden P, Hale G, Cornish JMM: Unrelated donor bone marrow transplantation for children with relapsed acute lymphoblastic leukemia in second complete remission. Br J Haematol 94:574, 1996

27. Hale G, Cobbold SP, Waldmann H, Easter G, Matejtschuk P, Coombs RRA: Isolation of low-frequency class-switch variants from rat hybrid myelomas. J Immunol Methods 103:59, 1987

28. Bridges J, Dowding C, Galton J, Hows J: Comparison of in vitro cytolytic activity of two preparations of CAMPATH-1M. XIV Annual Meeting of the European Cooperative Group for Bone Marrow Transplantation. Chamonix, France, April 10-13, 1988, p 163 (abstr)

29. Frame JN, Sheehy D, Cartagena T, Cirrincione C, O-Reilly RJ, Dupont B, Kernan NA: Optimal conditions for in vitro T cell depletion of human bone marrow by Campath-1M plus complement as demonstrated by limiting dilution analysis. Bone Marrow Transplant 4:55, 1989

30. Nash RA, Pepe MS, Storb R, Longton G, Pettinger M, Anasetti C, Appelbaum FR, Bowden RA, Deeg HJ, Doney K, Martin PJ, Sullivan K, Sanders J, Witherspoon RP: Acute graft-versus-host disease: Analysis of risk factors after allogeneic marrow transplantation and prophylaxis with cyclosporine and methotrexate. Blood 80:1838, 1992

31. Cox DR: Regression analysis and life tables (with discussion). J R Stat Soc B34:187, 1972
32. Klein JP, Moeschberger ML: Survival Analysis: Techniques for Censored and Truncated Data. New York, NY, Springer Verlag, 1997

33. Theobald M, Hoffmann T, Bunjes D, Heit W: Comparative analysis of in vivo $\mathrm{T}$ cell depletion with radiotherapy, combination chemotherapy and the monoclonal antibody CAMPATH-1G, using limiting dilution methodology. Transplantation 49:553, 1990

34. Moreau T, Coles A, Wing MG, Isaacs J, Hale G, Waldmann H, Compston A: Transient increase in symptoms associated with cytokine release in patients with multiple sclerosis. Brain 119:225, 1996

35. Wing MG, Moreau T, Greenwood J, Smith R, Hale G, Isaacs J, Waldmann H, Lachmann PJ, Compston DAS: Mechanism of first-dose cytokine release syndrome by CAMPATH-1H: Involvement of CD16 (Fc $\gamma$ RIII) and CD11a (LFA-1) on NK cells. J Clin Invest 98:2819, 1996

36. Gerritsen WR, Wagemaker G, Jonker M, Kenter MJH, Wielenga JJ, Hale G, Waldmann H, van Bekkum DW: The repopulation capacity of bone marrow grafts following pretreatment with monoclonal antibodies against T lymphocytes in rhesus monkeys. Transplantation 45:301, 1988

37. Starobinski M, Roosnek E, Hale G, Roux E, Helg C, Chapuis B: T-cell depletion of allogeneic peripheral blood stem cells (letter). Bone Marrow Transplant 21:429, 1998

38. Horowitz MM, Gale RP, Sondel P, Goldman JM, Kersey J, Kolb HJ, Rimm AA, Ringden O, Rozman C, Speck B, Truitt RL, Zwaan FE, Bortin MM: Graft-versus-leukemia reactions after bone marrow transplantation. Blood 75:555, 1990

39. Gale RP, Horowitz MM: How best to analyze new strategies in bone marrow transplantation. Bone Marrow Transplant 6:357, 1990

40. Frassoni F, Labopin M, Gluckman E, Prentice HG, Vernant JP, Zwaan F, Granena A, Gahrton G, De-Witte T, Grathohl A, Reiffers J, Gorin NC: Results of allogeneic bone marrow transplantation for acute leukemia have improved in Europe with time-A report of the acute leukemia working party of the European group for blood and marrow transplantation (EBMT). Bone Marrow Transplant 17:13, 1996

41. Parreira A, Smith J, Hows JM, Smithers SA, Apperley J, Rombos Y, Goldman JM, Gordon-Smith EC, Catovsky D: Immunological reconstitution after bone marrow transplant with Campath-1 treated bone marrow. Clin Exp Immunol 67:142, 1987

42. Roux E, Helg C, Dumont-Girard F, Chapuis B, Jeannet M, Roosnek E: Analysis of T-cell repopulation after allogeneic bone marrow transplantation: Significant differences between recipients of T-cell depleted and unmanipulated grafts. Blood 87:3984, 1996

43. Lowdell MW, Craston R, Ray N, Koh M, Galatowicz G, Prentice HG: The effect of $\mathrm{T}$ cell depletion with Campath-1M on immune reconstitution after chemotherapy and allogeneic bone marrow transplant as treatment for leukaemia. Bone Marrow Transplant 21:679, 1998

44. Hertenstein B, Hampl W, Bunjes D, Wiesneth M, Duncker C, Koszinowski U, Heimpel H, Arnold R. Mertens T: In vivo/ex vivo T cell depletion for GVHD prophylaxis influences onset and course of active cytomegalovirus infection and disease after BMT. Bone Marrow Transplant 15:38, 1995

45. Condiotti R, Nagler A: Campath-1G impairs human natural killer (NK) cell-mediated cytotoxicity. Bone Marrow Transplant 18:713, 1996

46. Hokland M, Jacobsen N, Ellegaard J, Hokland P: Natural killer function following allogeneic bone marrow transplantation. Very early re-emergence but strong dependence of cytomegalovirus infection. Transplantation 45:1080, 1988

47. Zeis M, Uharek L, Glass B, Steinmann J, Dreger P, Gassmann W, Schmitz N: Allogeneic MHC-mismatched activated natural killer cells administered after bone marrow transplantation provide a strong graft-versus-leukaemia effect in mice. Br J Haematol 96:757, 1997

48. Rooney CM, Wimperis JZ, Brenner MK, Patterson J, Hoffbrand AV, Prentice HG: Natural killer cell activity following T-cell depleted allogeneic bone marrow transplantation. Br J Haematol 62:413, 1986 
49. Reittie JE, Gottlieb D, Heslop HE, Leger O, Hazlehurst G, Drexler HG, Hoffbrand AV, Prentice HG, Brenner MK: Endogenously generated activated killer cells circulate after autologous and allogeneic marrow transplantation but not after chemotherapy. Blood 73:1351, 1989

50. Lowdell MW, Ray N, Craston R, Corbett T, Deane M, Prentice HG: The in vitro detection of anti-leukaemia-specific cytotoxicity after autologous bone marrow transplantation for acute leukemia. Bone Marrow Transplant 19:891, 1997

51. Jiang YZ, Barrett AJ, Goldman JM, Mavroudis DA: Association of natural killer cell immune recovery with a graft-versus-leukemia effect independent of graft-versus-host disease following allogeneic bone marrow transplantation. Ann Hematol 74:1, 1997

52. Hale G, Waldmann H, for CAMPATH users: Risks of developing
EBV-related lymphoproliferative disorders following $\mathrm{T}$ cell depleted marrow transplants. Blood 91:1, 1998

53. Willemze R, Richel DJ, Falkenberg JHF, Hale G, Waldmann H, Zwaan FE, Fibbe WE: In vivo use of CAMPATH-1G to prevent graft-versus-host disease and graft rejection after bone marrow transplantation. Bone Marrow Transplant 9:255, 1992

54. Hamblyn M, Marsh JCW, Lawler M, McCann SR, Dunlop L, Ball S, Davies G, Hale G, Waldmann H, Gordon-Smith EC: CAMPATH-1G in vivo confers a low incidence of graft-versus-host disease associated with a high incidence of mixed chimerism after BMT for severe aplastic anaemia using HLA sibling donors. Bone Marrow Transplant 17:819, 1996

55. Jacobs P, Wood L, Fullard L, Waldmann H, Hale G: T-cell depletion by exposure to CAMPATH-1G in vitro prevents graft-versushost disease. Bone Marrow Transplant 13:763, 1993 